\title{
The (Slow) Tragedy of Improvement: Neoliberalism, Fisheries Management \& the Institutional Commons
}

\author{
Patrick Bresnihan \\ Trinity College Dublin, Ireland
}

\section{A R T I C L E I N F O}

\section{Article history:}

Available online 6 November 2017

\section{Key words:}

commons

neoliberalism

governmentality

fisheries

Europe

Ireland

\begin{abstract}
S U M M A R Y
This paper contributes theoretically and empirically to debates on the relationship between neoliberalism and the institutionalization of the commons through an analysis of recent efforts to implement community-managed lobster fisheries in Ireland. This initiative has been influenced by international examples of co-management systems in small-scale, inshore fisheries, and is presented as a "third way" for resource management, moving beyond the limited management choice of privatization or centralized state control. The paper is based on interviews and fieldwork with the fisheries managers, scientists, and inshore fishermen involved in the development of the co-management plan. In the paper, I use the analytic framework of governmentality to examine how these efforts to institutionalize the fisheries commons represent both continuity and discontinuity with the long tradition of liberal thought and biopolitical "improvement". I argue that the continuity stems from the initial formulation of the problem of overfishing as one of unregulated exploitation of a resource; the novelty lies in the critique of existing institutional models, namely privatization and state regulation, that fail to adequately reflect and enable the capacities of local communities to self-manage the resources they exploit. Understanding neoliberal governmentality in terms of "improvement" helps us to understand and take more seriously the rationale behind efforts to devise better institutional responses to the problem of overfishing. The concept of "improvement" helps to broaden the analysis of neoliberalism beyond an often narrowly defined focus on market mechanisms and profit incentives; it shifts the focus of analysis away from the regulatory moments of "enclosure" to the ongoing, often frustrated efforts to align fishers' economic interests with the "long-term" common good. The article argues for a more ambivalent reading of the commons that places greater focus on how localized, collective action can be valued and incorporated within evolving governmental and economic arrangements.
\end{abstract}

() 2017 Elsevier Ltd. All rights reserved.

\section{Introduction}

Since the late 1970s, scholars and resource managers have been promoting the commons as an alternative narrative and institutional response to the dominance of neoliberal economic accounts of environmental degradation. The re-valorization of the commons as a complex and diverse set of norms and rules for managing shared resources is set against the well-known and persistently popular account of the "tragedy of the commons" (Dietz et al., 2003). Coined by Garret Hardin in 1968, the tragedy narrative reproduces a central tenet of liberal economic thought. In Hardin's account, individuals will continue to degrade common or shared resources unless they are 'coerced' through state regulation or incentivized through the allocation of private property rights (Hardin, 1968). This interpretation of society-nature interaction orientates around the assumed limits of (biophysical) nature and (economic) man; effective management of common resources must thus proceed in respect of these limits, even if this requires the uneven allocation of rights: "injustice is preferable to ruin", as Hardin succinctly put it. In contrast, the promise and potential of the commons lies in challenging the narrow economic selfinterest of individuals, and the narrow understanding of biophysical nature as a series of discrete, finite resources. Rather than dismissing the capacities of individuals to come together and collectively manage shared resources as part of complex socioecological systems, the re-valorization of the commons opens a whole new field of inquiry, analysis, and institutional experimentation that targets these capacities.

Significantly, the potential benefits of collective action for resource management have not been lost on the very institutions and inheritors of the liberal tradition that many commons advocates may have challenged in the past. As early as 1992, the World Bank stated, "Governments need to recognise that smaller organizational units, such as villages or pastoral associations, are better 
equipped to manage their own resources than are large authorities and may be a more effective basis for rural development and rational resource management than institutions imposed from the outside" (World Bank, 1992, p. 143). ${ }^{1}$ Support for communitybased resource management in the context of neoliberal restructuring, specifically the devolution of responsibility from more centralized state institutions to individual citizens and communities, has provoked critical scholars to question the extent to which localized, commons-based forms of organization provide an alternative or an extension of neoliberal rationalities (Bakker, 2008; De Angelis, 2013). One area that has been particularly rich for such debates is fisheries management.

The problem of overfishing has been framed as a classic "tragedy of the commons" since the 1950s, a decade or more before Hardin coined the term (see Mansfield, 2004). Ostrom herself has identified the problem of overfishing as resulting from a situation of "open access" in which commercial fishermen are effectively incentivized to overexploit fish stocks (Ostrom, 2000). As a result, fisheries have been managed through both direct state regulation and, more recently, the allocation of individualized, exclusive rights of access (Crean \& Symes, 1995), with the latter identified as a classic form of neoliberal environmental governance: the enclosure of the commons through the allocation of individualized property rights (Mansfield, 2004; St. Martin, 2005). In the literature, both 'top-down' management and privatization have been subjected to sustained critique (McCay, Creed, Finlayson, Apostle, \& Mikalsen, 1995; Ostrom, 2008), with community-based fisheries management put forward as a 'third way' beyond these limited management choices. Yet, critical scholars have examined how this 'third way' can continue to reproduce a defining feature of neoliberal fisheries management, namely the use of property regimes to harness the profit-motive of individual fishers (Mansfield, 2007). To disrupt the neoliberal fixation on property regimes and market rationality, these scholars argue for closer attention to be paid to the commons as a form of socio-ecological organization beyond the reductive economic rationalities of neoliberalism and the accumulation strategies of capital. This call to move beyond neoliberal forms of fisheries management has frequently involved efforts to map and foreground the social norms, community economies, and ecologically attuned fishing practices that contribute to more sustainable fisheries production, particularly in small-scale fisheries (St. Martin, 2000, 2009; Pinkerton, 2016; Pinkerton \& Davis, 2015).

This paper contributes theoretically and empirically to debates on the relationship between fisheries management, neoliberalism, and the institutionalization of the commons. Using the analytic framework of governmentality, I argue for a more dynamic understanding of neoliberalism as a reflexive form of governmental reasoning and practice that seeks to "improve" the health and security of the population (Foucault, 2004; Li, 2007; Rose, 2006). In the context of environmental governance, and sustainable development more generally, a key locus of contemporary biopolitical "improvement" has been the protection of natural resources and ecosystems. It is the imperative to ensure the re/production of these biophysical systems (for the common good) that today generates diverse and novel forms of enclosure in the name of sustainability

\footnotetext{
${ }^{1}$ Perhaps most telling in this respect is the recognition that the work of Elinor Ostrom, one of the best-known proponents of the commons, has received from libera scholars. As Mark Pennington writes: "At the core of Ostrom's work is the insight that many, though not all, of the free-rider and collective-good problems that are usually presented as requiring external regulation may be better addressed by relying on the ingenuity of those most affected by them to devise an appropriate set of rules. This is an insight that is close to the heart of the classical liberal tradition and which has prompted a new generation of scholars to catalogue cases where we observe the formation of rules without the exercise of external authority" (Pennington, 2012: 40-41; my emphasis).
}

(not capital as such, even though new sites of commodification and accumulation may be created). In the context of fisheries management, this is manifest through various institutional, technical, and market arrangements that require fishermen to demonstrate how sustainable and efficient their fishing activity is even as they are forced to compete in a global seafood market. Enclosure from this perspective does not just refer to the implementation of individual, private property rights over previously common resources (such as the fisheries), but to any institutional boundary that excludes some sections of the population from access to previously common resources on the basis of bio-economic calculation i.e., the aligning of economic interests, biophysical resources, and wider market dynamics (Jeffrey et al., 2012). In this article, I focus on what I call the logic of "improvement" to foreground the extended process of neoliberal governmental reflection and knowledge production that generates and justifies novel forms of enclosure in the fisheries.

Empirically, the paper is based on sixteen months of fieldwork in Castletownbere, a commercial fishing port in the South West of Ireland. This fieldwork was part of bigger research project examining transformations in the governance of the Irish and European fisheries sector (see Bresnihan, 2016). Part of this fieldwork focussed on the Irish inshore fisheries. This involved interviewing and going fishing with over a dozen inshore fishermen, as well as interviews with the key fisheries managers and fisheries scientists working for over ten years on a plan to implement communitymanaged lobster fisheries around the Irish coast. ${ }^{2}$ This initiative began in the 1990s in response to declining numbers of lobsters, the main commercial species for inshore fishermen. Inspired by the example of the co-managed Maine lobster fisheries, lobster fishermen, fisheries scientists, and fisheries managers sought to introduce a similar framework for regulating access to the lobster fisheries. Explicit from the start was a desire to avoid the potentially negative social and economic consequences of individual transferable rights of access, while at the same time ensuring some level of security to enable more effective management of the lobster stocks. As I show in section three of the paper, this approach to fisheries governance departs from other forms of neoliberal fisheries management that have sought to harness the narrow, economic self-interest of fishermen. A key insight put forward by my analysis is that efforts to implement community-based fisheries management in Ireland explicitly seek to incorporate (not exclude) the complex socio- economic and ecological attributes of specific fisheries by enabling fishermen to take on more of a role in the management of the fish stocks they exploit. This is important because it complicates the more familiar account of neoliberalism as a simplifying and/or exclusionary form of power: neoliberalism does simplify and exclude, but it also values and seeks to incorporate complexity.

The foregrounding of complexity and unpredictability in relation to environmental management has encouraged managerial solutions that target the situated, responsive and collective capacities of local communities. As I show in section three, fishermen and their interactions with lobster, each other, the market, and so on, are not just acted on, but are brought into the field of governmental reflection and intervention: the transition from an unregulated, relatively unknown (from the perspective of the state) inshore fisheries sector, to a draft implementation plan that has yet to be implemented, illustrates how the qualities and attributes of both fishermen and fish stocks are actually generated through the practice of government itself, namely the discursive and material practices that map, measure and seek to arrange productive relationships between fish stocks and fishing communities.

\footnotetext{
${ }^{2}$ None of these fisheries managers and scientists lived in the commercial fishing port where I was based for my fieldwork. The fieldwork drawn on for this article involved traveling to the offices of these individuals which are scattered across Ireland.
} 
These practices are all calculated to incite real, i.e., measurable, changes in the conduct of fishermen, the way they relate to their activity, environment, each other and the market. This represents the extension of a modern biopolitics of improvement that ties the health or re/productivity of the population to calculable forms of knowledge (Bresnihan, 2016; Li, 2007). This perspective becomes useful in understanding how the continued failure to implement the lobster management plan is explained by either the reluctance or inability of fishermen to commit to the "longer term" sustainability of the marine environment, an explanation that further incites efforts to create the conditions in which fishermen will be able to make such commitments. In the final section of the paper, I describe this as the "(slow) tragedy of improvement". Understanding biopolitical improvement as part of a longer, dynamic process of reflection on the failure of existing forms of government (and the knowledge that underpins them) challenges familiar readings of neoliberalism as a relatively fixed ideology orientated around a narrow conception of the economic subject and property rights.

\section{Situating the commons}

In her seminal text Governing the Commons, Elinor Ostrom makes it clear where her motivation for researching the rules and institutions of collective action lies: the power of certain dominant narratives for explaining the causes of resource degradation and the limited choice of management strategies that arise as a result. For Ostrom and her colleagues, the 'inevitability' of the tragedy was based on the inaccurate portrayal of resource users as "helpless individuals caught into an inexorable process of destroying their own resources" (Ostrom, 2008, 8). As Ostrom concludes, “ [a]s long as individuals are viewed as prisoners, policy prescriptions will address this metaphor. I would rather address the question of how to enhance the capabilities of those involved to change the constraining rules of the game to lead to outcomes other than remorseless tragedies" (2008a, 7). By re-presenting individual resource-users as deliberative agents capable of arriving at mutually agreed solutions to resource-based problems a whole new field of inquiry into institutions for collective action is opened (Agrawal, 2003; Forsyth \& Johnson, 2014). The focus of this inquiry has tended to be on real-world settings where rules, norms, and knowledge practices governing resource use and access have proven successful, often for centuries. As Forsyth and Johnson (2014) argue, this "positive, rather than normative" approach to institutions and their role in shaping social, political and economic life has been central to the re-working of institutional approaches to the commons. ${ }^{3}$ The emphasis on empirical case studies, a resistance to "one-size-fits-all" solutions, and the goal of designing institutional models that work "on the ground" in often messy, diverse contexts, has appealed to resource managers frustrated with the apparent inefficacy of existing institutional models, particularly in a context of worsening problems of resource degradation (Acheson \& McCay, 1990; Agrawal, 2003; Leach, 2008). Underlying critiques of existing models of environmental management is a critique of the forms of knowledge and analysis that guided such models, particularly the capacity of top-down, scientific expertise to achieve effective management in diverse, complex and dynamic socio-ecological contexts (Berkes, Colding, \& Folke, 2000; Berkes \& Folke, 1998).

Critical scholars have pointed to the ways community-based resource management can replicate and extend dominant neoliberal rationalities, rather than providing substantial alternatives.

\footnotetext{
${ }^{3}$ Governing the Commons, they write, was part of a highly influential series published co-edited by James Alt and Douglas North, whose work on the institutional foundations of economic and political life was highly influential in the American social sciences (Forsyth \& Johnson, 2014).
}

By assuming that individuals will degrade and ultimately destroy common resources unless subject to norms and regulation appears to reproduce the basic assumption of the "tragedy of the commons" narrative (De Angelis \& Harvie, 2014; Goldman, 2001; Turner, 2016). Empirically-informed analysis of the ambivalent relationship between the commons and neoliberalism has been particularly rich in the critical scholarship on contemporary fisheries management. The work of Becky Mansfield is particularly instructive in this regard $(2004,2007)$. She traces the origins of neoliberal approaches to fisheries management back to the 1950s and the work of fisheries economists like Scott Gordon who asserted that "[t]he fish in the sea are valueless to the fisherman, because there is no assurance that they will be there for him tomorrow if they are left behind today" (Gordon, 1954, p. 125). In Mansfield's analysis, the persistence and continuity of the "tragedy' narrative provides a common point of departure for different neoliberal property regimes (private, state, and community) that all seek to regulate the economic self-interest of individual fishermen through the profit incentive. In this way, Mansfield makes a distinction between common property regimes that reproduce neoliberal assumptions and seek to harness market rationalities to resolve problems of overfishing, and those that foreground issues of social justice, equitable access, and social protection from the market (2007).

Mansfield's distinction between neoliberalism (privatization, profit motive, market penetration), and neoliberalism's 'other' (equitable access, social norms, market protections) resonates with other critical scholarship on small-scale fisheries. Kevin St. Martin, for example, writes, "[t]he assumed subject of fisheries (the utility maximising competitive individual) and the space within which that subject operates (the open access commons) have the effect of erasing and/or displacing the cooperative and territorial practices of fishermen embedded within fishing communities" (2007, 543). In response to this 'hegemonic' neoliberal gaze, St. Martin affirms the need to map and demonstrate the 'otherness' of the fisheries commons as a "unique non-capitalist formation within an economy conceptualized as diverse", a practical and imaginative departure from the cyclical processes of capitalist commodification and neoliberal enclosure. Similarly, in a special issue edited by Pinkerton and Davis on neoliberalism and fisheries management in North America, there is a strong correlation made between the neoliberal re-structuring of social and environmental relations and the expansion of capitalist accumulation. Against this dynamic, several papers argue that small-scale fisheries can provide a point of resistance in terms of the contributions they make to public welfare, "by promoting more economically beneficial equality and adapting to climate change and recession" (Pinkerton \& Davis, 2015, p. 310).

Critiques of neoliberal fisheries management thus tend to focus on and challenge the reductive depiction of fishers as profitmotivated economic agents and the negative social and economic impacts of privatization (Barnett, Messenger, \& Wiber, 2016; Carothers, 2008). From this perspective, neoliberal fisheries management is taken to be "inflexible, maladaptive, and dictatorial, and unable to take advantage of the substantial efficiency benefits offered by small-scale fisheries" (Pinkerton \& Davis, 2015, p. 309), demonstrating a "disconnect that often occurs between neoliberal policies and the local knowledge and practices that usually characterize small-scale fisheries" (Pinkerton \& Davis, 2015, p. 308). Often aligned with a critique of capitalist accumulation, the literature also tends to identify how the extension of exclusive property rights allows for the reproduction of capital, even going so far as to suggest that neoliberal policies are implemented in service to capitalist interests (Pinkerton \& Davis, 2015).

As I show in the next section, the fisheries managers and scientists responsible for implementing co-management plans in the 
Irish inshore fisheries also hold variations of these critiques of exclusive, individualized access rights, top-down knowledge, and the dominance of extractive forms of capitalism. However, rather than these positions representing a clear departure from neoliberal approaches of the past I argue that they remain consistent with basic aspects of neoliberal economic reasoning and governmental practice. This is significant because it questions the extent to which drawing clear distinctions between 'neoliberal' and 'nonneoliberal' subjectivities and relationships is the best way to conceptualize the relationship between the commons and neoliberalism today. In order to tease out the continuities and discontinuities between neoliberal forms of governance in the fisheries I now turn to Foucault's analytic framework of biopower/governmentality.

In the last of his 1976 lectures at the College de France and in his book The History of Sexuality, Foucault introduced the concept of biopower to describe a new form of power that emerged in the latter half of the eighteenth century in Europe. Rather than a power of 'deduction' (the legal deprivation of goods, products, services, and, in extreme cases, life itself from political subjects), biopower was characterized by a logic of 'production', "a power bent on generating forces, making them grow, and ordering them, rather than one dedicated to impeding them, making them submit, or destroying them" (Foucault, 1998, p. 136). Foucault describes how the target of this new form of power is not a body of individual legal subjects, or bodies capable of "entrained performances", but a population, "a multiplicity of individuals who are and fundamentally and essentially only exist biologically bound to the materiality within which they live" $(2004,21)$. The challenge for the State or Sovereign was how to govern this population, which consisted of properties and dynamic relationships that were neither entirely knowable nor amenable to control (Foucault, 2008). As Foucault writes, 'If one says to a population 'do this,' there is not only no guarantee that it will do it, but also there is quite simply no guarantee that it can do it" (Foucault, 2004, 71). The nature of the population thus becomes a limit on power, something that must be acknowledged and obeyed if government is to ensure the ongoing health and security of the population.

It is in addressing the question of how to govern the population that a new liberal "art of government" or governmentality, as Foucault calls it, emerges. This form of governing is not concerned so much with "imposing law on men but of disposing of things: that is of employing tactics rather than laws, or even of using laws themselves as tactics-to arrange things in such a way that, through a certain number of means, such-and-such ends may be achieved" (Foucault, 1991, 95; emphasis added). To devise the most appropriate way of governing men and things, of arranging re/productive relationships between them, more precise knowledge about their properties and the relationships between them is required. This opens the space for a new productive relationship between knowledge and power, that is, the techniques and technologies for mapping, measuring, categorizing and, ultimately, representing men and things are inseparable from the ways they are valued, organized and 'disposed of'. This new relationship between power and knowledge generates what Foucault calls a "regime of truth", in which the 'truth' of 'falsity' of a government policy or intervention is not located in an abstract, external system of transcendental value but in its measurable effects in the world. As Thomas Lemke writes regarding governmentality as a new rationality of power: "[t]he coordinates of governmental action are no longer legitimacy or illegitimacy but success or failure" (Lemke, 2011, 46).

Scholars researching community-based resource management and development since the 1990s have used the analytic framework of governmentality to demonstrate how state projects enroll local subjects and territories through techniques and technologies of decentralized governance (Agrawal, 2006; Li, 2005; Lockie, 1999; Mosse, 1997). These analyses are helpful in demonstrating how environmental projects are constructed over time through the messy, sometimes contradictory, efforts of administrators, scientists, civil servants, NGOs, and communities themselves. These projects of improvement (Li, 2007) are understood as productive of new subjects and environments, rather than simply negative or exclusionary: the rolling out of development projects provides opportunities for inclusion as well as exclusion. As Arun Agrawal writes, "policies aiming at greater decentralisation and participation are about new technologies of government. To be successful, they must redefine political relations, reconfigure institutional arrangements, and transform environmental subjectivities" $(2006,7)$. And while property regimes are a key part of this process, they are part of a broader constellation of discursive and material interventions that aim to foster new ways of perceiving, valuing and interacting with the world (Dardot \& Laval, 2014). Understood from this perspective, neoliberalism is neither just about the withdrawal of the state or the advance of the market, but "an opportunity to rearrange the ways in which rule is accomplished, while also offering communities an opportunity to realign their position within (but not outside) the state system" (Li, 2002, p. 278).

A more recent body of Foucauldian scholarship (Braun, 2015; Reid, 2013; Mezzadra, Reid, \& Samaddar, 2013) argues that a shift in the focus of biopolitical regulation has been occurring since the 1970s that helps explain the foregrounding of local community capacities and knowledge. While environmental factors were always part of efforts to manage the population (and thus subject to mapping, measurement and management) throughout the 19th and 20th centuries, this was only in so far as they supported the health and well-being of the human population. Since the 1970s, however, the environment has ceased being simply a backdrop/ resource for human economic activity, becoming instead a vital and complex support system on which all other activities depend (Braun, 2015; Nelson, 2015). Generic concepts such as 'sustainable development' thus indicate a fundamental shift in the focus of development, "not simply from the economy to a wider understanding of human well-being, but from the development of human life to the non-human "life support systems" which peoples are said to depend on in order to live well and prosper" (Reid, 2013, p. 354). This historic shift is important for understanding changes within environmental governance, particularly the valorization of local forms of knowledge and resilience in a context of growing ecological risk and complexity (Joseph, 2013; Vardy \& Smith, 2017); as Pugh (2014) asserts, "changing understandings of the environment matter because [they] work to change the stakes of governmental rationalities and practices".

The tendency toward prioritizing the biological sustainability of fish stocks within fisheries management is clear in the case of European fisheries policy. The most recent reform of the European Common Fisheries Policy (CFP) in 2013 established for the first time in its thirty-year history a strategy to manage the fisheries from the perspective of the biological health of the fish stocks (rather than the economic expansion of the fishing industry). Prioritizing the biological performance of fish stocks establishes a "common" (measurable) goal for fisheries managers, scientists, citizens, and the fishing industry to work toward. These developments have prompted far-reaching and critical reflections on the structural failings of existing fisheries management and the need for radical changes in how the problem of overfishing is understood and what new approaches are required (Bresnihan, 2016). Incorporating the fishing industry as an active participant in the management of fish stocks (rather than simply an economic exploiter of fish stocks) is identified as necessary for achieving sustainable fisheries 
(Commission for Environmental Cooperation, 2008). In terms of fisheries governance this means re-scaling roles and responsibilities "down" to the fishers: "[s]o, we need to enhance the aspect of de-centralized decision-making", former EU Commissioner for Fisheries, Maria Damanaki, stated, "[i]ssues that are merely technical do not belong to the political level” (Damanaki, 2011, p. 2). This neoliberal discourse of decentralized governance is giving rise to diverse institutional, legislative, technical and market arrangements that aim to address the "common" problem of depleting fish stocks. It is in the light of these on-going debates and experiments that attempts to institutionalize community-based management in the Irish inshore fisheries needs to be situated.

\section{Governing better}

Historically, inshore fisheries have been the social and economic mainstay of small coastal communities in Ireland. ${ }^{4}$ The main species targeted are crab, lobster, scallops, prawns and, to a lesser degree, assorted flatfish. The most valuable inshore species in terms of earnings is the lobster. Compared to the offshore fishing industry, the inshore sector has not experienced rapid technological advances or overcapitalization in terms of expanded fishing capacity. And while inshore fish stocks have declined over the past few decades, they are not under the same kind of pressure as offshore fish stocks. Consequently, the inshore sector is often described in policy documents as "traditional" or "artisanal."

In 1994, regional lobster fishing associations and co-operatives first formed around Ireland under the umbrella of the Irish Lobster Association (ILA). During the sixteen months of fieldwork I carried out in Castletownbere, one of the largest commercial fishing ports in Ireland, I got to know one of the leading figures in the ILA, a fisherman named Tom O'Sullivan. ${ }^{5}$ He told me about a visit he and other representatives made to Maine in 1994. They had been invited by the Maine Lobster Association (MLA), which was successfully moving at that time toward a form of co-managed lobster fisheries that would ensure that the lobster fishermen had direct control over their fishing activity. Inspired by the example of the Maine lobster fisheries and mobilized by the partial success of recent collective actions, several groups of inshore fishermen in Ireland, mostly from the south coast, began pushing for the introduction of statutory regulations on fishing and some form of community-managed lobster fishery framework.

Maeve O'Reilly (fisheries manager with Bord Iaschaigh Mhara ${ }^{6}$ [BIM]), James Carney (fisheries scientist with the Marine Institute ${ }^{7}$ ), and Brid Smith (civil servant in the Department of Agriculture, Marine and Fisheries) are three individuals who were centrally involved in the development and design of a community-based strategy for managing the Irish lobster fisheries. Along with Tom O'Sullivan, all three believed that the main problem with the decline in lobster stocks was the lack of regulation governing the inshore fisheries. "Well I think if I was a lobster fisherman at the moment, irrespective

\footnotetext{
${ }^{4}$ The inshore sector describes a territorial area as well as a type of fishing: the inshore extends out six nautical miles from the national coast of each European member state and refers to vessels of less than $12 \mathrm{~m}$. In Ireland the inshore sector accounts for about half of all those employed in the fishing industry and over three quarters of the vessels in the fishing fleet. Figures from 2007 show that the inshore sector accounted for 1,400 of the 1,800 vessels in the entire fleet. The inshore sector employs about 2,300 fishermen out of a total of 4,900 in the entire sector. Despite making up such a large proportion of the fleet and fishermen, the inshore sector only lands $20 \%$ of the total catch-value of the Irish fisheries (Bord Iascaigh Mhara, Managing Access to the Irish Lobster Fishery).

${ }^{5}$ All names of respondents have been changed to protect their anonymity.

6 The state agency with responsibility for developing the fishing industry.

7 The national body responsible for undertaking, coordinating and promoting marine research in Ireland.
}

of how much I want to see the long term, I don't think I could act in the long term," Carney told me. "I couldn't be proactive because the management system doesn't allow me to. It effectively forces me into a short-term view. So that has to change certainly" (2009; my emphasis). He went on: "If you look at the problem with the lobster fishery at the moment, it's not due to bureaucracy, it's due to a lack of bureaucracy, a lack of collective action and talking" (Damanaki, 2011). Maeve O'Reilly echoed this point, identifying the underlying conflict between the "short-term" actions of fishermen operating in an unregulated fishery, and the need for the "long-term" sustainability of the fisheries. The challenge for her and other fisheries managers, scientists, and fishermen, was in aligning the interests, and thus actions, of individual fishermen with the long term "common" good of sustainable fisheries.

Tracing the cause of overfishing to the unregulated activity of individual fishermen exploiting limited natural resources is where institutional approaches to the commons and the long tradition of liberal thought coincide. At the same time, however, the fisheries managers and scientists involved also understand that inshore fishers are not inherently self-interested or driven by the pursuit of profit. After all, the initial impetus for managed access to the fisheries came from the lobster fishers' organizations themselves. Unlike more familiar depictions of neoliberal responses to overfishing that emphasize 'simplistic' solutions that orientate around the need to limit the activities of fishermen (private rights of access or top-down state regulation), the position of the fisheries managers and scientists is that inshore fishermen need to be enabled to better manage their own resources. The positive rationale behind institutions for collective action is that fishermen can and should be supported to take collective decisions and actions that benefit themselves and the fish stocks they exploit. ${ }^{8}$ It is in seeking to devise better ways of governing the "unregulated" commons that the novelty of institutions for collective action lies. As the example of the Irish inshore fisheries demonstrates, seemingly benign efforts to "improve" the management of the fisheries commons can create novel forms of enclosure.

In the case of the Irish inshore fisheries (and inshore fisheries globally), top-down state regulation, or "management by centre" as Brid Smith (2009) called it, has never been a desirable or feasible option. Historically, the alternative to direct state management of fisheries has been the allocation of exclusive, individual and transferable rights of access (Crean \& Symes, 1995). However, in the case of the Irish inshore fisheries, fisheries managers, scientists, and the associations of inshore fishermen were unified in wanting to avoid transferable rights of access primarily because of social

\footnotetext{
${ }^{8}$ The 'naturalization' of the complex problem of resource depletion has been a perennial target for political ecologists, anthropologists, and sociologists since Marx's scathing attacks of Malthus and liberal political economy. As Lyla Mehta, one of the foremost scholars on the politics of scarcity, summarizes in the introduction to an edited collected on 'the limits to scarcity': '“scarcity' has emerged as a totalizing discourse in both the North and the South with science and technology often expected to provide solutions, but such expectations embody a multitude of unexamined assumptions about the nature of the 'problem', about the technologies and about the so-called institutional fixes that are put forward as the 'solutions"' (2013: 2). Underlying assumptions about the 'nature' of scarcity, she goes on, generate 'simplistic' and often inappropriate solutions that re/produce new forms of exclusion. While broadly in agreement with the critical impetus of this argument, it is the contention of this article that the 'solutions' that are generated in response to the 'problem' of resource depletion are not simplistic. From the analytic perspective of governmentality, the solutions that are generated in response to problems like overfishing are not plucked out of thin air (according to some ideological conviction), but emerge out of a longer process that incorporates techno-scientific work (mapping, measuring, gathering data), property rights and other legal instruments, and market devices, that are coordinated to bring about effects that come to be seen as necessary for the re/productivity of the resources.
} 
equity concerns. ${ }^{9}$ Both Maeve O'Reilly and James Carney identified the risk of "aggregation" (concentration of the resource in few hands), quoting the example of the Tasmanian rock lobster fishery where Individual Transferable Quotas (ITQs) had created monopolies within fisheries that had previously supplied an "expanded social benefit". As Carney summarized: “[t]he one thing we're saying with the lobster is you can have an exclusive right, but not a transferable right-that's the difference with ITQ. That will enable the long-term view without creating this great cost for the next generation who want to get into the fishery". This socially oriented commitment to avoiding ITQs was also combined with a belief that communitybased fisheries management provided other benefits, such as collective responsibility and action, that would contribute to the overall aim of achieving sustainable fisheries.

The initial challenge to introducing a co-management framework for the Irish inshore fisheries was the lack of knowledge about the fisheries. As James Carney told me: "If you look at attention paid to it [lobster fisheries] prior to 2000, it was almost zero. I don't think there was a scientific paper published between 1963 and 1995 , or a policy paper. So it's a blank sheet from the state's point of view" (2009). In response, BIM began identifying the numbers of fishermen and vessels operating in the inshore sector as a first step toward designing a management plan (BIM, 1999). They soon discovered that half the boats operating commercially were not even licensed. Many of the smaller fishermen had not bothered to sign up because, as one fisheries manager told me, "the idea of bothering to license his boat was just mad". Many of these boats were just small punts with an outboard motor, and anyone who lived by the coast and wanted to catch a few crab or lobsters on the side could do so. The licensing of all active fishing boats was understood to be a necessary step toward the implementation of a management structure for the inshore fishery.

Additional knowledge about the different species targeted, catch levels, the distribution of fishermen between fishing ports, and the fishing grounds they used, were also incorporated into the design of the management framework. These data were gathered through industry-science initiatives which encouraged lobster fishermen to monitor their own fishing activity, recording where and what they caught, as well as nation-wide consultations with representatives from local inshore fisheries advisory committees set up as part of the process. For Carney, the fisheries managers, and the inshore fishermen actively involved in consulta-

\footnotetext{
9 The wider debate over the relative merits of ITQs as a fisheries management tool for the European fisheries is not directly related to the inshore fisheries but helps illustrate how neoliberal policies should not simply be caricatured as 'ideological' givens. The more salient point is that the debates around ITQs are not qualitatively different from those involving community-managed fisheries i.e., it is not whether ITQs are good or bad in principle (i.e., market price is the best way to allocate resources) but what the potential impacts may be on specific fisheries in relation to a whole series of concerns (e.g., will quotas be more enforceable, will fish populations benefit, will fishing capacity be reduced, will the value of the fisheries be monopolized), and how potentially negative impacts can be ameliorated e.g., through limits on the trade of quotas. In Ireland, for example, ITQs have not been implemented because of the potentially negative social and economic impacts it may have on a fishing industry that is still relatively under-capitalized, community-based and consisting of trawlers that are owner-operated (rather than the vertically integrated fishing companies in countries like Spain and the Netherlands). A good example of this pragmatic (neoliberal) approach to ITQs comes in the form of a report on ITQs by the Canadian NGO, EcoTrust. The report emphasizes the potential efficacy of ITQs as part of a "holistic" form of fisheries management. While the report offers a critical account of the negative social and ecological consequences of ITQs in the salmon fisheries in British Columbia, it concludes that ITQs are not in themselves the problem: "[d]ebate about TQs is often polarized and fueled more by ideology than reality.... Downplayed is the critical role that sound science and good governancethat is, inclusive, transparent co-management between government, and industry and stakeholders-play in ensuring the sustainability of fisheries. The central lesson of this brief investigation into ITQs is that there are no simple solutions or quick fixes to fisheries conservation. If properly designed, ITQ systems can play an effective role in a multi-faceted approach to responsibly managing fisheries" (EcoTrust, 2009, p. 1).
}

tions on the fisheries management plan, these data were necessary to determine the most appropriate scale for the territorial units that would form the basis of the management plan. As Carney put it: "to establish at what scale will the fishermen and the lobsters be enabled to organize and engage in productive relations with each other?".

This goes some way to explain why it was not until 2008, more than a decade after Tom's visit to Maine, that BIM published a consultation document for the lobster fisheries. Managing Access to the Irish Lobster Fishery (BIM, 2008) provided the basic outline for a management plan for the lobster fishery and offered a blueprint for the management of other inshore fish species. The Irish coast was to be divided into eight zones or territories. Each of these zones was to be broken into two additional units to allow more flexibility for those fishermen who were working on the boundary between two units. While the Irish lobster fishery has nothing like the well-developed territories and "gangs" of the Maine lobster fishery, the decision to create localized zones was based on the need to create a sense of ownership among small communities of fishermen over particular lobster stocks.

The significance of the proposed plan was that for the first time a form of regulated access to the lobster fishery would be legislated for and enforced by the state. Fishermen who currently had a license to fish for lobster would be issued an authorization that would allow them to fish for lobster within their zone. There was a limit placed on the number of authorizations issued. These authorizations could not be bought or sold and thus did not function as a tradable right of access. There were no criteria set for how many pots a fisherman could set, but the expectation was that the security promised by the limited entry for fishermen and the scale of the fishing zones would foster collaboration and collective decision making in the management of the fish stocks. As Carney put it,

The setting up of management units, limited access, and managed entry to those units is the first basic step to address the sustainability issue. Now you have managed access, when you have managed access the group can collectively act. They may wish to reduce effort at a certain rate, to improve the cost benefit. So it gives them scope for more action essentially....

[(my emphasis)]

Rather than instituting individualized, private access rights as a means of inciting competition between individuals, the institutional approach to the commons seeks to enable cooperation between fishermen by defining collective access rights over fisheries. Referring to the creation of territorial units, O'Reilly described this as an important step toward the fostering of a "social infrastructure" that would provide the basis for achieving the goals of sustainable development-in terms of the biological sustainability of the fish stocks, economic viability, and social inclusion. Underlying this was a recognition that fishermen are socially embedded, innovative, and knowledgeable of their own environments, properties that can enable local actors to 'do it better' than can be done through the unmediated imposition of regulatory schemes (Van der Ploeg, 2009).

James Carney explained how important changes in fisheries science since the 1990s were promoting more collaborative approaches to fisheries management. He related the experience of the Maine lobster fishery as a turning point in this regard. Up until the early 1990s, marine scientists in Maine had been using a recruit model as a means of understanding the population dynamics of the lobster fisheries. A recruit model compares the number of new eggs produced in a year with the number of fish caught in the same period. Because the levels of egg production were very low, the prediction models suggested that the stock was about to collapse. But it didn't even though the Maine lobster 
fishermen were increasing their fishing effort and landing more lobsters. This was a complete contradiction of the science, which in turn undermined the credibility of the scientists and the recommendations that they called for. With the support of some marine biologists and researchers, the lobster industry argued that this apparent anomaly-high catch rates and high lobster populations-owed partly to how fishermen managed access to the fishery and the fishing activity itself (Acheson, 2003). ${ }^{10}$ When the scientists finally took a step back and consulted the fishermen the result, Carney told me, was "like a chain being removed, all of these new ideas came forward, new models, new data provision, better indicators, more cooperation because the fishermen didn't feel threatened anymore" (2009; emphasis added).

Carney recounted this experience to explain that the main problem facing the Maine lobster fisheries in the 1980s was not a disagreement over the data being collected but the model of science itself. The recruit model assumed that fish stocks were discrete, quantifiable resources that were only affected by levels of exploitation by fishermen. This model failed to account for the inherent unpredictability of fish population dynamics and the potentially beneficial fishing practices and knowledge employed by fishermen. Responding to these capacities, the new model of fisheries management thus entails a clear departure from previous models that sought to base decisions on scientific certainty and the imposition of clear limits (i.e., quotas) on fishing activity. This new model is now not only being applied to small-scale fisheries, such as the lobster fisheries, but fisheries management more generally. As Carney told me:

In the case of lobster, we haven't gone down the road of trying to assess population abundance really, or even in making forecasts about abundance, or future catches and future population sizes. ... There's a move away from using those predictive models to using what we would call just simple indicators of the current status of the stocks. So rather than having an absolute estimation of something, you have a relative indicator. So you're looking for trends over a period of time rather than absolute point estimates at particular points in time. So they are different scientific approaches. The scientific approach and the certainty with which scientists can make an estimate is also related to, and in some way defines, the way the management system works... hence the move toward the more co-management model rather than a top-down situation. So I think it's important that the scientific work which is traditionally seen as the starting point is now seen as one seat at the table, and can give its opinion, and is only one opinion. That is where we are at the moment I think.

[(emphasis added)]

According to Carney, any 'workable' management system had to incorporate uncertainty and flexibility, reflecting the complex biological, social, and economic dynamics of the fisheries. Carney describes here a process rather than a singular regulatory event or shift in how the fisheries are managed: "relative indicators" trace patterns and tendencies over time that allow fisheries scientists, managers, and fishermen themselves to identify whether certain actions are effective vis-à-vis the measurable bio-economic performance of the fishery. As one of the BIM consultation documents put it, the co-managed approach is a "form of experimental adaptive management [that] is highly suited to stocks which are structured geographically, and where the relative effects of fishing

\footnotetext{
10 Acheson argues that the tendency of the Maine lobster fishermen to adopt practices that regulate how fishing is done, rather than simply regulating how many fish are caught, appears around the world in small-scale fisheries. "These rules are unusual in that they are designed to maintain critical life processes," Acheson writes (2003, 228; emphasis added).
}

and environment on catch rates are unknown" (Tully, 2004, p. 4; emphasis added). Replacing the hierarchy of scientific expertise, awareness of the uncertainty and dynamism of marine ecosystems is resulting in the demand for more grounded, co-produced and flexible forms of decision-making that are assessed by their efficacy vis-à-vis specified and measurable goals, rather than abstract claims to universal validity (see Forsyth, 2003; Pellizzoni, 1999). Working to improve the performance of simple indicators, such as the status of the lobster stock in an area, thus provides a common, measurable point around which fishermen, scientists, and fisheries managers can come together to devise localized, experimental and technical solutions to the problem of overfishing.

\section{The (slow) tragedy of improvement}

While Irish lobster associations have been making proposals for some form of managed access to the lobster fisheries since the early 1990s, and a management plan reflecting these demands was published in 2008, nothing has yet been implemented. O'Reilly, who has been involved in fisheries management since the late 1990s, was clearly frustrated: "Here we are at the end of ten years and we don't have a lobster management plan. After all those initiations and iterations of a process that you had fishermen involved in, for the right reasons if you like, in terms of sustainability, viability, both economic and biological" (2009).

The situation suddenly changed in 2012 because of Ireland's commitment to European biodiversity directives. Under the EU Birds and Habitats Directive (2001), a network of nature conservation sites known as Natura 2000 sites were established around Ireland, including in many coastal areas. These conservation areas required the Irish government to collect biological baseline data through its conservation agency, the National Parks and Wildlife Service (NPWS). In 2007, the EU Commission brought five complaints against the Irish government for failing to adequately classify or protect several important areas. The EU threatened heavy fines unless the Irish government complied with the directive. Previously peripheral areas along the coast suddenly became a priority for the state. The reforms mandated assessments of all licensed activities, including fishing, taking place within these designated areas to make sure they did not adversely affect key species. The need to demonstrate that fishing was being carried out sustainably gave a new impetus to the lobster co-management framework. O'Reilly said that lobster fishermen "will now do anything to be involved" because of the threat of the European directives (and potential exclusion from the fisheries entirely). Although most inshore fishermen do not have a significant impact on biodiversity within coastal environments, the directive would require them to demonstrate this through management plans and evidence of fishing impacts. While O'Reilly was disappointed that it took this kind of regulatory pressure to galvanize fishermen and the Irish Government into acting on the management plan she welcomed the positive effects it was having.

In the end, the threat of European sanctions for noncompliance with Natura 2000 did not materialize, and the plans to manage access to the lobster fishery were put on hold. In a subsequent email exchange in 2014, O'Reilly told me that the management plan had come to a standstill again partly because of government "foot-dragging," but mostly because of the "short-term" attitude and lack of support for managed access of lobster fishermen themselves. When I pushed her to specify who these fishermen were or why they were against a system of managed access, she told me they were the established, full-time lobster fishermen with polyvalent licenses (access to both non-quota shellfish and quota finfish)-those who were, "ironically", most dependent on the health of the fish stocks. Among other concerns, these fishermen 
were fearful that the new management plan would reduce the value of their tonnage. ${ }^{11}$ O'Reilly told me that a biologically wellmanaged fishery should outweigh the asset value of an individual's tonnage. The lack of support from these established inshore fishermen was, for her, a good example of how "short-term" selfinterest continued to trump collective actions for the "long term" good. For O'Reilly, this lack of progress on the implementation of the co-managed inshore fisheries was clearly frustrating. This frustration was in part directed at the lack of departmental support to drive the issue, and in part at the fishermen themselves whose initial enthusiasm for such a scheme appeared to have waned.

I went fishing several times with Joe, a young, full-time lobster fisherman who had been involved in the initial consultations on the inshore co-management plan. He understood the need for some sort of regulation but was wary of the proposed licensing system. To begin with it did not differentiate between different kinds of fishermen. The government's decision in the early $2000 \mathrm{~s}$ to grant a free potting license to all inshore boats had effectively granted a green light to anyone with a boat to target crab and lobster. But these part-time fishermen often had other sources of income and thus didn't rely on the fishing. In Joe's words, "they didn't care for the fish", meaning they fished too many pots, or left their pots down for too long because they forgot about them. There are currently no formal rules about these things but because Joe relied on the lobsters coming back each year he, and other fulltime fishermen, had to recognize these limits in the areas where they fished; the decisions Joe makes on an everyday basis do not entirely begin and end with him. He does strategize to make a living, but he is also embedded within social and ecological contexts and relationships that are negotiated on an ongoing basis. For example, Joe relies on other fishermen whom he knows personally. He relies on them not to overfish the stock, or to fish pots across his own, but he may also rely on them for a loan of fishing gear if his own breaks down, to help him on the boat at short notice, or to share knowledge about where fishing may be good. It is hard to pinpoint or explain this kind of ethos, one that does not simply orientate around the exploitation or management of a resource but the more complex sharing of an ill-defined territory consisting of multiple resources. ${ }^{12}$ This locally situated but widely distributed economy of exchange and reciprocity does not neatly fit within a formal institutional model. Importantly, this is not lost on the fisheries scientists and managers involved in the management of the inshore fisheries. They spoke about the extent of "good-will" and the "conservationist ethos" that existed among inshore fishermen. The challenge was in creating the appropriate institutional parameters that would encourage and enable these qualities to come to the fore. To date this had not been successful, which for Joe related to the second, arguably more significant limitation of the co-management plan.

This main criticism that Joe had of the proposed licensing system was that it did not address the declining price of fish. Inshore fishing was hardly viable anymore according to Joe. It did not matter how healthy or how well regulated the stock was-a fisherman could not survive off his income. At the time, the price of lobster was $€ 9.50 / \mathrm{kg}$ instead of $€ 13 / \mathrm{kg}$ the year before, and brown crab

\footnotetext{
11 Tonnage represents the share of the quota allocated to a particular boat: the larger the tonnage the higher proportion of the allocated quota a boat will receive. Tonnage can be sold between boats, but unlike tradable quotas, the transfer of tonnage tends to be a one-time event, usually when a fisherman leaves the fishery. In the absence of a decent pension, fishermen commonly see tonnage as a capital asset that can be realized when they retire from fishing. The reason why polyvalent licenseholders in the inshore fisheries opposed any system of managed access to the lobster fishery was that any limits on who can come in and out of the fishing zones would effectively mean a reduced market for their tonnage.

12 I have discussed in more detail this vision of the "more-the-human commons" elsewhere (See Bresnihan, 2015).
}

was $€ 1 / \mathrm{kg}$ rather than $€ 3 / \mathrm{kg}$. While prices fluctuated, Joe could only see things getting worse as buyers and middlemen dominated the European market. This effected Joe's fishing practices directly, eroding his ability to "care" for the fish that he caught. The first day I went potting with Joe, the processing factory had told him they were not accepting the bodies of crabs because they could not sell them. The processing factory had been in decline, and Joe was worried he would have nowhere to sell his catch. He had no choice but to rip the claws off all the crabs-maybe two to three hundred. It is illegal to rip both claws off the crab because without them they have no way of hunting, essentially ensuring they die. Joe was also aware of how painful it must be for the animal. Joe knew all this but had no choice. Not only did he run the risk of a fine and a criminal record if he was caught, but he also thought it was a "terrible waste of good meat." The more that Joe is exposed to the vagaries of the uneven seafood market, the less possible it is for him to care for the fisheries (and community) he relies on. ${ }^{13}$ The pressure to align one's activities-from ripping off crab claws to increasing the number of pots fished-to the demands of the market is identified as the main driver of depleting fish stocks, not the lack of formal institutions and allocation of access rights.

When asked about the economic pressures facing lobster fishermen, O'Reilly accepted that these were real but that the only realistic way of combatting this situation was through concentrating on what fishermen could control, namely working together with other fishermen and fisheries managers to ensure the fish stocks they relied on were performing well, thereby enhancing their economic viability. For O'Reilly, the challenge was to move beyond what she described as "grumbling" about fish prices, which are "beyond the control" of fishermen, to more positive action directed toward aspects of their activity they can influence: "All you want to do is say, 'This is the area you mainly fish in, you get to decide how many pots should be fished in that area including yourself.' It's not about limiting you as much as saying address the issues in this area, concentrate your thing here, what do you want, what are your targets, do you want to increase catch rate and so on" (2009; emphasis added). Brid Smith also acknowledged that fishermen wanted a higher price for their catch but believed that such aspirations were unrealistic in what she called the "world economic climate". ${ }^{14}$ She also sought to emphasize the positive ways local fishermen could respond to this situation by collectively managing fish stocks to ensure sustainable fish stocks and sustainable livelihoods.

O'Reilly and Smith were not unaware of the economic pressures and competition inshore fishermen faced. But they emphasized that fishermen were not "helpless", that there were things they could do to improve their economic viability. This depended on them working together in a regulated fishery. While they were frustrated and disappointed about the failure of the management plan (to date), they believed the only answer was to continue working through the various "obstacles" that were arising, by working harder to bring fishermen together, inform them about the long-term benefits of collectively managing their fisheries and enabling them to do that through institutional interventions and supports. This was articulated by Brid Smith as a commitment to "getting things right on the ground": "[i]nternational experience

\footnotetext{
13 Bird Rose describes something similar when she writes how a white settler regards his relationship to the place he lives and works as "spiritual." He understands the place, Nature, as an "active force, something living, something to be encountered," even though he is also involved in economic practices that have undermined and destroyed it (Rose, 2004). Although fishermen are the primary exploiters of the fisheries, their relations to the marine environment are, to different degrees, more complex than this narrowly economic one. Although fishermen are inserted within circuits of production and accumulation, they are also part of everyday naturecultures that have escaped the enclosure and separation of modern space and time.

14 This attitude was also widely shared by the fishermen I worked with during my fieldwork.
} 
tells us bottom up, bottom up, bottom up and not to force the process, just keep going back and back until you are driven demented by the whole process". To reinforce her point, Smith described a recent development with crab fishermen on the West coast. These fishermen had approached BIM looking to gain environmental accreditation for their crab. Accreditation is a market-based instrument that promises to reward sustainable fishing practices through the added-value accredited fish products gain at the point of sale (Foley \& McCay, 2014). While there are many types of accreditation scheme for the fisheries a basic requirement is the ability to demarcate the fishery and the fishermen participating in the accreditation scheme. Beyond this, fishermen must also be able to monitor the fish stocks, enforce regulations, and ultimately comply with the criteria for the specific accreditation scheme. For Smith, this was an example of how fishermen taking the initiative to market their catch could drive plans for the co-management of the inshore fisheries, and vice versa. The point was that marketing opportunities like eco-labels could encourage fishermen to work collectively by demonstrating that a biologically sustainable fishery could also be a profitable fishery. As has been documented elsewhere, for example, these eco-accreditation schemes also function to both commodify certain (measurable) forms of environmental performance and exclude fishermen who do not have the financial, scientific and institutional supports, or motivations, to achieve such accreditation (Bresnihan, 2016; Foley \& McCay, 2014; Ponte \& Cheyns, 2013). ${ }^{15}$

Through her account of the "will to improve" in Indonesia, $\mathrm{Li}$ (2007) shows how the failure of development projects to achieve desired outcomes does not necessarily lead to the abandonment of such projects entirely. Rather, such failures can provide the impetus for further reflection, data gathering, and analysis that elicit new kinds of governmental intervention. The commitment of the fisheries managers and scientists in the Irish context to conserving lobster stocks and ensuring sustainable livelihoods for inshore fishermen provides a good example of this "will to improve". Ultimately, the failure of the co-management plan to materialize after nearly twenty years reinforces (rather than challenges) the assumption that individual fishers are unable (because of a lack of appropriate institutional support) to align themselves with the "long-term" common good. This can lead to frustration, cynicism, even exhaustion, on the part of those involved (including fishermen who are actively involved through the consultation process). But it can also lead to a re-doubling of efforts to equip fishermen with the knowledge, security, incentives, and so on, to take more collective action. As the example of the threat of EU fines and the promise of an accreditation scheme suggest, diverse tactical 'levers' can be used to galvanize "action on the ground". Whether these are territorially defined access rights as developed through the co-management scheme, eco-accreditation schemes, or more familiar top-down state regulations (driven by EU environmental directives), the impetus and effects of these governmental measures are similar. The motivation is to measurably "improve" the interactions between fishers and the fish stocks so that the generic goals of sustainable development can be advanced. Consistent with the apolitical rationale of neoliberal governmentality, these "improvements" are developed without challenging the systemic drivers of overfishing.

\section{Conclusion}

Efforts to manage the fisheries commons through communitybased institutions represent both continuity with and a novel

\footnotetext{
15 As De Angelis (2013) writes, “[i]n this way 'commoning' is annexed to a divisive, competitive process in order to keep the whole game going."
}

departure from liberal forms of government of the past. The continuity stems from the initial formulation of the problem of overfishing as one of unregulated exploitation of a common resource; the novelty lies in the critique of existing institutional models, namely privatization and state regulation, that fail to adequately reflect and incorporate the capacities of local communities to selfmanage the resources they exploit. An important distinction between neoliberal fisheries governance today and that of the past is that the driving impetus behind the design of institutional boundaries, including those governing access rights, is premised on enabling the constructive qualities and capacities of individual resource users working together, rather than simply limiting their economic self-interest. This in turn opens a more extensive and malleable terrain for governmental reflection and intervention. As outlined in section three, the task of creating territorial units for managing the Irish lobster fisheries was based on the gathering of data about the socio-economic, geographic, and biological properties of the fisheries through ten years of inquiry and consultation between fishermen, fisheries managers, and fisheries scientists. The motivation for this process was to get the institutions right, to graft a framework for collective action onto the realities on the ground such that real, measurable effects would be generated. Ultimately, no co-management plan has been implemented but this has not led to the complete abandonment of the plans. As discussed above, the enforcement of EU biodiversity legislation, as well as the promise of market-based accreditation schemes, arise as potentially decisive new interventions for galvanizing fishers (and the central government) into advancing the co-management strategy.

Understanding neoliberal governmentality in terms of improvement helps us to understand and take more seriously the genuine investment of fisheries managers, scientists, and fishermen themselves, as they seek to devise better institutional and technical responses to the problem of overfishing. The concept of improvement works as a productive counterpoint (rather than alternative) to the more familiar understanding of neoliberalism as enclosure. Enclosure refers to the regulatory moment, legislative instrument, or market device, that excludes some and includes others from access to resources. Often, and understandably, the critical focus is placed on these points or moments of enclosure and the negative social (and environmental) effects they can generate. There is less attention paid in the critical literature, however, on the way enclosures are devised, justified and extended-other than pointing to neoliberal 'ideology'. The concept of improvement responds to this gap by focussing on the technical, scientific, and discursive work that provides the justification for novel and diverse forms of enclosure. In the case of the Irish lobster fisheries, it is possible to see how efforts to better understand and coordinate the conduct of fishermen and the biological dynamics of lobster stocks (within the limits of the market) gives rise to a "regime of truth" within which specific interventions (access rights, enforcement of biodiversity legislation, eco-accreditation) and actions (fishermen's reluctance to participate) are justified and understood.

As outlined above, the primary goal of the co-management plans for the Irish inshore fisheries is not to increase the profitability of some sections of the industry, nor even to entrain fishermen to perform in pre-defined ways. The goal is to foster collective action among specific groups of fishers so they can better manage specific fish stocks and adapt to the "world economic climate". It is important to emphasize that the 'failure' of the co-management plan is not due to the inflexibility of 'top-down' administration or the inability to incorporate local knowledge and needs. Or rather, these are challenges that those involved in designing the co-management scheme are keenly aware of and willing to address. The weakness (and strength) of the co-management plan as it has unfolded since the 1990s is that it is resolutely committed 
to galvanizing local, collective action to address systemic, 'nonlocal' problems that are inseparable from the deepening commodification of the fisheries. Significantly, this effort is not incompatible with 'positive' outcomes and solutions. For example, the crab fishery in Mayo could implement a regulated fishery and achieve valuable eco-accreditation that in turn could raise the incomes of the fishermen involved, supporting the sustainability of that community. And just as the co-management of the Maine lobster fisheries are held up as an example of a successful managed commons, encouraging and driving similar efforts around the world, so too would a successful eco-accreditation scheme be used as evidence to extend such initiatives.

Recognizing that neoliberal governmentality is not primarily driven by capitalist strategies of accumulation (though it may support them), or generative of only 'negative' outcomes, alerts us to calls that too readily affirm the existence of 'non-neoliberal' or 'non-capitalist' alternatives in the midst of a monolithic capitalist system (Gibson-Graham, 2008). As outlined in Section 2, there is a tendency to identify neoliberal fisheries management in terms of private property regimes, market rationality, and narrowly defined economic subjects. This identification gives rise to affirmations of neoliberalism's 'other': the social and ecological relationships, practices and values that are excluded from the narrow economic calculus of neoliberal governance. One of the consequences of this analysis is that efforts to render these 'nonneoliberal' practices and values visible are generally understood as a positive step toward diversifying socio-economic strategies and models of fisheries production, to building alternatives to neoliberal enclosure and capitalist accumulation. Undoubtedly, these diverse socio-economic and ecological practices and subjectivities do offer an important counter-point and resistance to individual transferable access rights or the pressure to overexploit fish stocks due to market exposure. But it is also important to identify how these collective re/productive capacities can also be aligned with new forms of biopolitical improvement and enclosure that continue to orientate around the demand for resource-users to assume more responsibility for managing resources and to devise strategies for adapting to uncertain economic and environmental conditions.

In her work on the 'peri-capitalist' frontiers of Matsutake mushroom ecologies and the precarious livelihoods of mushroom pickers, Anna Tsing (2015) shows the multi-form character of global commodity chains that rely on non-capitalist relations and sites of re/production-what she calls the "latent commons". From this perspective, capital does not simply enclose the commons through privatization ('accumulation by dispossession') but appropriates the commons from a distance, rendering it a kind of infrastructure for the 'productive' economy (see Moore, 2015). ${ }^{16}$ The imperfect, fragile and ad hoc nature of the latent (mushroom) commons she describes corresponds closely with the "unregulated" (fisheries) commons that fishermen like Joe are a part of. Similar to the precarious lives of the mushroom pickers, Joe and other inshore fishermen are caught between localized, situated economies and ecologies that rely on relationships of reciprocity and care, and the need to remain commercially viable when operating at the bottom of a competitive, high-value commodity chain. Efforts to institutionalize the commons as a form of community-managed resource seek to resolve these deep-rooted tensions by encouraging and enabling collective action. This can involve the fostering of social norms, diverse economic practices, and local knowledge, qualities that are not familiarly understood as either 'neoliberal' or 'capitalist'. Critical scholars need

\footnotetext{
16 This echoes what feminist scholars have argued for several decades in relation to social reproduction more generally, namely the historic ambivalence of the commons as both a site for non-capitalist relations of re/production, and a site of 'free' (unwaged) labor appropriated by capital (Federici, 2011)
}

to be cautious of positions that too equate neoliberal governance with 'simplification', with the resulting call to include more social and ecological diversity and capacity, potentially driving further rounds of improvement and enclosure. Similarly, criticisms of the bureaucratic, 'top-down' nature of environmental management are immanent to neoliberal governmentality, energizing new efforts to galvanize local resource-users to take more initiative. This article has contributed to debates on the relationship between neoliberalism and the commons by troubling any neat distinctions between 'good' (i.e., 'non-neoliberal') and 'bad' (i.e., 'neoliberal') versions of the institutional commons. By emphasizing the ambivalent role and value of the commons within dynamic forms of neoliberal governance today, this article argues for greater criticality when it comes to affirming the benefits of the commons as an alternative to dominant forms of economic production and decision-making.

\section{References}

Acheson, J. M. (2003). Capturing the commons: Devising institutions to manage the Maine lobster industry. UPNE.

Acheson, J. M., \& McCay, B. J. (Eds.). (1990). The question of the commons. The Culture and ecology of communal resources. Tuscon: University of Arizona Press.

Agrawal, A. (2003). Sustainable governance of common-pool resources: Context, methods, and politics. Annual Review of Anthropology, 32, 243-262.

Agrawal, A. (2006). Environmentality: Technologies of government and the making of subjects. Durham and London: Duke University Press.

Bakker, K. J. (2008). The ambiguity of community: Debating alternatives to privatesector provision of urban water supply. Water Alternatives, 1(2), 236-252.

Barnett, A. J., Messenger, R. A., \& Wiber, M. G. (2016). Enacting and contesting neoliberalism in fisheries: The tragedy of commodifying lobster access rights in Southwest Nova Scotia. Marine Policy (2016).

Berkes, F. Colding, J., \& Folke, C. (2000). Rediscovery of traditional ecological knowledge as adaptive management. Ecological Applications, 10(5), 1251-1262.

Berkes, F., \& Folke, C. (Eds.). (1998). Linking social and ecological systems. Management practices and social mechanisms for building resilience. Cambridge: Cambridge University Press.

BIM (1999). Irish inshore fisheries sector. Review and recommendations.

BIM (2008). Managing access to the Irish lobster fishery.

Braun, B. (2015). The 2013 Antipode RGS-IBG Lecture. New materialisms and neoliberal natures. Antipode, 47(1), 1-14.

Bresnihan, P. (2016). Transforming the fisheries. Neoliberalism, nature, E' the commons. University of Nebraska Press.

Bresnihan, P. (2015). The more-than-human commons: From commons to commoning. In L. Dawney et al. (Eds.), Space, power and the commons: The struggle for alternative futures. New York: Routledge.

Carothers, C. (2008). Rationalized out: Discourses and realities of fisheries privatization in Kodiak, Alaska. In Enclosing the fisheries: People, places and power (Vol. 68, pp. 55-74).

Commission for Environmental Cooperation (2008). A European Strategy for Marine and Maritime Research: A Coherent European Research Area Framework in Support of a Sustainable Use of Oceans and Seas. European Commission.

Crean, K., \& Symes, D. (1995). Privatisation of the Commons: The introduction of individual transferable quotas in developed fisheries. Geoforum, 26(2), 175-185.

Damanaki, M. (2011). The future of the common fisheries policy is now. Speech/11/ 418.

Dardot, P., \& Laval, C. (2014). The new way of the world: On neoliberal society. Verso Books.

De Angelis, M. (2013). Does capital need a commons fix? Ephemera: Theory \& Politics in Organization, 13(3), 603-615.

De Angelis, M., \& Harvie, D. (2014). The commons. In M. Parker, G. Cheney, V. Fournier, \& C. Land (Eds.), The routledge companion to alternative organization (pp. 280-294). London: Routledge.

Dietz, T., Ostrom, E., \& Stern, P. C. (2003). The struggle to govern the commons. Science, 302(5652), 1907-1912.

EcoTrust (2009). Briefing - A cautionary tale about ITQs in BC fisheries.

Federici, S. (2011). Feminism and the Politics of the Commons. www.thecommoner. org (last accessed 18th September 2017).

Foley, P., \& McCay, B. (2014). Certifying the commons: Eco-certification, privatization, and collective action. Ecology and Society, 19(2), 28.

Forsyth, T. (2003). Critical political ecology: The politics of environmental science. London: Routledge.

Forsyth, T., \& Johnson, C. (2014). Elinor Ostrom's legacy: Governing the commons, and the rational choice controversy. Development and Change, 45(5), 1093-1110.

Foucault, M. (1991). The Foucault effect: Studies in governmentality. University of Chicago Press.

Foucault, M. (1998). The history of sexuality, Vol. 1: The will to knowledge. London: Penguin Books.

Foucault, M. (2004). Security, territory, population. Lectures at the College de France, 1977-1978. US: Palgrave MacMillan. 
Foucault, M. (2008). The birth of biopolitics. Lectures at the College de France, 19781979. US: Palgrave MacMillan.

Gibson-Graham, J. K. (2008). Diverse economies: Performative practices for other worlds'. Progress in Human Geography, 32(5), 613-632.

Goldman, M. (2001). Constructing an environmental state: Eco-governmentality and other transnational practices of a "green" World Bank. Social Problems, 48 (4), 499-523.

Gordon, S. H. (1954). The economic theory of a common-property resource: The fishery. The Journal of Political Economy, 124-142.

Hardin, G. (1968). The tragedy of the commons. Science, 162(3859), 1243-1248.

Jeffrey, A., McFarlane, C., \& Vasudevan, A. (2012). Rethinking enclosure: Space, subjectivity and the commons. Antipode, 44(4), 1247-1267.

Joseph, J. (2013). Resilience as embedded neoliberalism: A governmentality approach. Resilience, 1(1), 38-52.

Leach, M. (2008). Pathways to Sustainability in the forest? Misunderstood dynamics and the negotiation of knowledge, power, and policy. Environment and Planning A, 40(8), 1783-1795.

Lemke, T. (2011). Critique and experience in Foucault. Theory, Culture E Society, 28 (4), 26-48.

Li, T. M. (2002). Engaging simplifications: Community-based resource management, market processes and state agendas in upland Southeast Asia. World Development, 30(2), 265-283.

Li, T. M. (2005). Beyond "the state" and failed schemes. American Anthropologist, 107, $383-394$.

Li, T. M. (2007). The will to improve: Governmentality, development, and the practice of politics. Duke University Press.

Lockie, S. (1999). The state, rural environments, and globalisation: "action at a distance" via the Australian Landcare program. Environment and Planning A, 31 (4), 597-611.

Mansfield, B. (2004). Neoliberalism in the oceans: "rationalisation", property rights, and the commons question. Geoforum, 35, 313-326.

Mansfield, B. (2007). Articulation between neoliberal and state-oriented environmental regulation: Fisheries privatization and endangered species protection. Environment and Planning A, 39, 1926-1942.

McCay, B. J., Creed, C., Finlayson, A. C., Apostle, R., \& Mikalsen, K. (1995). Individual transferable quotas (ITQs) in Canadian and US fisheries. Ocean \& Coastal Management, 28(1-3), 85-115.

Mezzadra, S., Reid, J., \& Samaddar, R. (2013). The biopolitcs of development: Reading Michel Foucault in the postcolonial present. New Delhi: Springer.

Moore, J. W. (2015). Capitalism in the web of life. Ecology and the Accumulation of Capital, 172-181.

Mosse, D. (1997). The symbolic making of a common property resource: History, ecology and locality in tank-irrigated South India. Development and Change, 28 (3), 467-504.

Nelson, S. H. (2015). Beyond the limits to growth: Ecology and the neoliberal counterrevolution. Antipode, 47(2), 461-480.
Ostrom, E. (2000). Private and common property rights. In Encyclopedia of law and economics, Vol. II: Civil law and economics (pp. 332-379). Ghent, Belgium: University of Ghent.

Ostrom, E. (2008). Governing the commons: The evolution of institutions for collective action. Cambridge University Press.

Pellizzoni, S. H. (1999). Reflexive modernisation and beyond: Knowledge and value in the politics of environment and technology. Theory, Culture E Society, 16(4) 99-125.

Pennington, M. (2012). Elinor Ostrom, common-pool resources and the classical liberal tradition. In E. Ostrom, C. Chang, M. Pennington, \& V. Tarko (Eds.), The future of the commons-beyond market failure and government regulation. London: Institute of Economic Affairs.

Pinkerton, E. (2016). Hegemony and resistance: Disturbing patterns and hopefu signs in the impact of neoliberal policies on small-scale fisheries around the world. Marine Policy.

Pinkerton, E., \& Davis, R. (2015). Neoliberalism and the politics of enclosure in North American small-scale fisheries. Marine Policy, 61, 303-312.

Ponte, S., \& Cheyns, E. (2013). Voluntary standards, expert knowledge and the governance of sustainability networks. Global Networks, 13(4), 459-477.

Pugh, J. (2014). Resilience, complexity and post-liberalism. Area, 46(3), 313-319.

Reid, J. (2013). Interrogating the neoliberal biopolitics of the sustainable development-resilience nexus. International Political Sociology, 7(4), 353-367.

Rose, D. B. (2004). Reports from a wild country: Ethics for decolonisation. UNSW Press. Rose, N. (2006). Governing "advanced" liberal democracies. In A. Gupta \& A. Sharma (Eds.), The Anthropology of the state: A reader. Blackwell Publishing, Oxford.

St Martin, K. (2000). Mapping economic diversity in the First World: The case of fisheries. Environment and Planning A, 37, 959-979.

St. Martin, K. (2005). Disrupting enclosure in New England Fisheries. Capitalism Nature Socialism, 16, 63-80.

St. Martin, K. (2009). Toward a cartography of the commons: Constituting the political and economic possibilities of place. Professional Geographer, 61, 493-507.

Tsing, A. L. (2015). The mushroom at the end of the world: On the possibility of life in capitalist ruins. Princeton University Press.

Tully, O. (2004). Integration of biology and management in lobster fisheries. In O Tully (Ed.), The biology and management of clawed lobsters (Homarus gammarus L.) in Europe. Bord Iaschaigh Mhara.

Turner, M. (2016). Political ecology III The commons and commoning. Progress in Human Geography.

Van der Ploeg, J. D. (2009). The new peasantries: Struggles for autonomy and sustainability in an era of empire and globalization. Routledge.

Vardy, M., \& Smith, M. (2017). Resilience. Environmental Humanities, 9(1), 175-179. World Bank (1992). World Development Report 1992: Development and the Environment. US: Oxford University Press. 